\title{
Who's got water lapping at the door?
}

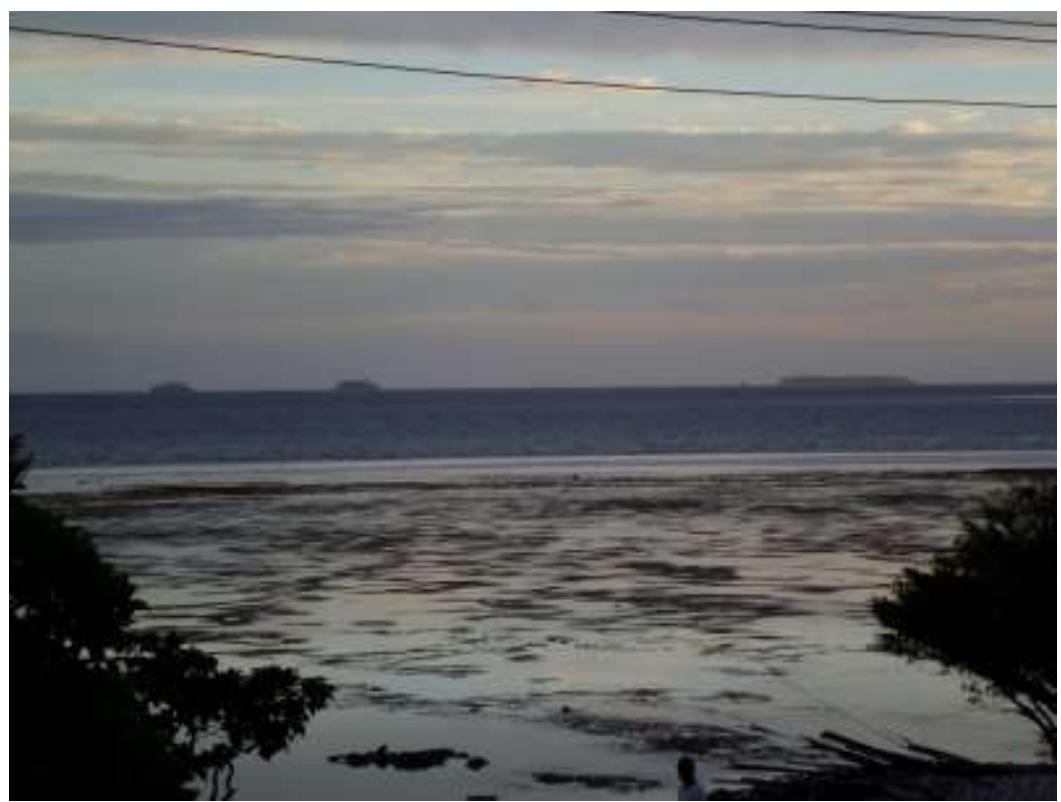

Photograph Credit: Teena Brown Pulu

Time doesn't mean anything when you're about to be, you know, have water lapping at your door.

Peter Dutton

Who did Australian immigration minister, Peter Dutton, think he was? Did Dutton honestly believe he, and fellow white Australians of the Liberal Party government, were completely immune to climate change? Did their whiteness and bigness of landmass offer protection from greenhouse gases and natural disaster, making them superior humans of 
the Asia Pacific region? What an uninformed politician in a position of absurd public power.

Australian, New Zealand, and British media framed the story wrong. It wasn't that Dutton got caught on camera performing his "water lapping at your door" slur against Pacific Islanders to the debunked Australian Prime Minister, Tony Abbott, which rendered him apologetic and slightly embarrassed.

Rather, it was that he failed to mentally grasp factors constituting cause and effect, and most importantly, his role as a political actor. The lesson may have been too much for him to take in at once.

Tony de Brum, a politician and Minister-in-Assistance to the President of the Marshall Islands, nailed the first point evading Dutton's social conscience.

Next time waves are battering my home and my grandkids are scared, I'll ask Peter Dutton to come over, and we'll see if he is still laughing.

Tony de Brum

There were disparate power relations in real politik. Countries forming the Pacific Islands region held unequal material and political interests. Australia and New Zealand were the developed and dominant states that ruled the roost. While Pacific Islands' states, on the other hand, were undeveloped and subordinate to the Western duo. Noting that, it was never taken in good spirit or humour when the wealthy, an Australian immigration minister and a former Prime Minister, were seen publicly sniggering about the plight of poor island countries struggling against climate change.

Subsequent to this was the question of human empathy. By not identifying with, and showing compassion for, climate affected Pacific Islanders, Dutton looked immoral and malicious. Would the Smaller Island States to the Pacific 
Islands Forum - Cook Islands, Kiribati, Marshall Islands, Nauru, Niue, Palau, and Tuvalu - trust the Liberal and National coalition government Dutton worked for?

These climate vulnerable states lobbied Australia and New Zealand to stand with them in advocating that the Conference of Parties to the United Nations Framework Convention on Climate Change held in Paris from November 30th to December 11th, 2015, "deliver a legally binding agreement, which will: a) Limit global average temperature increase to well below 1.5 degrees Celsius above pre-industrial levels." Australia and New Zealand refused to take on 1.5 to stay alive, settling for 2 degrees Celsius.

Jonathan Pearlman for The Telegraph reported at the time Dutton exchanged the gag, he and Abbott "were attending a discussion on the resettlement of refugees from Syria after [Tony] Abbott this week committed to taking an extra 12,000 Syrian migrants."

"It was a light hearted discussion with the PM," uttered Peter Dutton. Ushering an apology "to anyone who has taken offence" was intended to settle it. Pacific Islanders displaced by rising sea levels could now see Tony Abbott's point that it was merely "a lame joke."

But it wasn't "a lame joke" to the people being taunted, and Abbott's audacity to assume Dutton's apology was sufficient to patch up the offence and political fracture, was just as offensive as the prank itself.

Kiribati President Anote Tong was the first to call Peter Dutton out as "morally irresponsible" for trading a "vulgar joke." Being the most susceptible low-lying atolls, Dutton's clowning shocked the Smaller Island States to the Pacific Islands Forum.

What kind of a person is he? As long as there is this kind of attitude, this kind of arrogance in any position of leadership, we will continue to have a lot of tension. It shows a sense of moral irresponsibility quite unbecoming of leadership in any capacity. 
Tuvalu Prime Minister Enele Sopoaga spoke candidly to Koro Vaka'uta at Radio New Zealand. The Dutton incident affected his government's reluctance to work with Australian Aid. Who in their right mind would want Australia's development assistance "if that's the attitude" of their leadership?

That incident, somehow, has thrown out in broad daylight the mentality of the leadership. That incident couples with the attitude in the [Pacific Islands] Forum discussions - are confirming a rather different attitude - this is very disconcerting for Tuvalu. It makes us think about all our talks about partnerships, genuine partnerships, and friendship, and carevery, very disappointed. We are not sure if we'd be in a position to be in partnership with any assistance from Australia, if that's the attitude.

Could the Australian government be redeemed under Malcolm Turnbull, the new Prime Minister to replace Tony Abbott? Turnbull had to step up and face the music, rather than sending Australia's foreign minister Julie Bishop out among Pacific Islands' states to talk her way around climate crises.

In the meantime the same old scenario would drag on. Smaller Island States lobbying Australia and New Zealand to take the 1.5 degrees Celsius stand to the Paris climate change convention. Australia diplomatically sidestepping any real change on climate policy. With the ruptured relationship firmly under the microscope so that both sides - Smaller Island States versus Australia - could scrutinise each other's politics. 